\title{
Dental anomalies of a child with incontinentia pigmenti: Case report
}

\author{
Anomalias dentárias de uma criança com incontinência pigmentar: Relato de caso \\ Anomalías dentales en niño con incontinencia pigmentaria: Reporte de caso
}

Received: 06/22/2021 | Reviewed: 07/01/2021 | Accept: 07/28/2021 | Published: 08/03/2021

Wanessa Fernandes Matias Regis

ORCID: https://orcid.org/0000-0002-2755-7672

Federal University of Ceará, Brazil

E-mail: wanessaregis1@gmail.com

Beatriz Gonçalves Neves

ORCID: https://orcid.org/0000-0002-9599-0662 Federal University of Ceará, Brazil

E-mail: beatrizneves@ufc.br

Ramille Araújo Lima

ORCID: https://orcid.org/0000-0001-5764-7081 Christus University Center, Brazil

E-mail: ramille.lima@unichristus.edu.br

Francisco Ruliglésio Rocha

ORCID: https://orcid.org/0000-0003-4370-3294 Federal University of Ceará, Brazil

E-mail: rulio@ufc.br

Lidiany Karla Azevedo Rodrigues

ORCID: https://orcid.org/0000-0001-8060-8531 Federal University of Ceará, Brazil E-mail: lidianykarla@ufc.br

\begin{abstract}
Incontinentia Pigmenti is a rare multi-system dominant genetic disorder caused by a mutation of the IKBKG/NEMO gene, localized on the X-chromosome, locus Xq28, characterized by dermatological, ocular, neurological, and dental alterations. This case report shows Incontinentia Pigmenti dental findings and emphasizes the importance of the dentist's knowledge about these anomalies so that the patient can be regularly monitored throughout the development of the dentition. Keywords: Child, Incontinentia Pigmenti, Tooth Abnormalities.
\end{abstract}

Keywords: Child; Incontinentia Pigmenti; Tooth abnormalities.

\section{Resumo}

Incontinentia Pigmenti é uma doença genética multissistêmica dominante rara, causada por uma mutação do gene IKBKG / NEMO, localizada no cromossomo X, locus Xq28, caracterizada por alterações dermatológicas, oculares, neurológicas e dentais. Este relato de caso mostra os achados odontológicos da Incontinentia Pigmenti e enfatiza a importância do conhecimento do dentista sobre essas anomalias para que o paciente possa ser monitorado regularmente durante todo o desenvolvimento da dentição.

Palavras-chave: Criança; Incontinentia Pigmenti; Anormalidades dentárias.

\section{Resumen}

Incontinentia Pigmenti es un trastorno genético dominante multisistémico poco común causado por una mutación del gen IKBKG / NEMO, localizado en el cromosoma X, locus Xq28, caracterizado por alteraciones dermatológicas, oculares, neurológicas y dentales. Este informe de caso muestra los hallazgos dentales de Incontinentia Pigmenti y enfatiza la importancia del conocimiento del dentista sobre estas anomalías para que el paciente pueda ser monitoreado regularmente durante el desarrollo de la dentición.

Palabras clave: Niño; Incontinentia Pigmenti; Anormalidades dentales.

\section{Introduction}

Incontinentia Pigmenti (IP) or Bloch-Sulzberger syndrome is a rare multi-system X-linked dominant genetic disorder, in which dermatological alterations are present and usually combined with anomalies in other organs (Berlin et al., 2002). The mutation of NEMO (NF-kappa-B essential modulator), also known as IKK- $\gamma / \mathrm{IKBKG}$ inhibitor of nuclear factor kappa-B 
kinase subunit gamma gene, located on chromosome Xq28, is believed to play a role in the pathogenesis of this disease (Berlin et al., 2002; Smahi et al., 2000).

This syndrome affects almost exclusively females and is usually lethal in males (Berlin et al., 2002; CammarataScalisi et al., 2019). The IP diagnosis is mainly based on clinical manifestations, especially in the skin findings that appear at birth or the first few weeks (Minić et al., 2014). Skin lesions along Blaschko's lines (lines of normal cell development in the skin) start in the neonatal period and evolve four stages: (I) vesiculobullous; (II) verrucous; (III) hyperpigmented; and (IV) hypopigmentation (Landy \& Donnai, 1993).

The skin changes are the main characteristic of IP, however, these alterations may regress or even fade over time (Marques et al., 2014). Clinical manifestations vary considerably and may involve ocular, dental and central nervous system (CNS) abnormalities (Yang et al., 2014). Dental manifestations are already known as part of the phenotypic spectrum of IP, but still without a full understanding of its causes and implications for the general health of affected individuals (Poziomczyk et al., 2014). The aim of this case report is to discuss the oral manifestations and management of a child with IP.

\section{Case Report}

A six-year-old girl was referred to a pediatric dental office from Fortaleza, Brazil with a complaint of "separation" between two teeth. Perinatal history revealed that the child was born to non-consanguineous parents and vaginal delivery with no associated complications at birth. Medical history revealed two previous miscarriages. The informed consent was obtained and signed by her mother. The patient's anonymity was respected.

The mother reported that at the time of the child's birth, pustules and vesicles were present throughout the body. Initially, the medical diagnosis indicated congenital syphilis. Then, the patient was submitted to various treatments with topical and systemic medications for the skin lesions, albeit without success. By 4 months of age, after several medical examinations, the Incontinentia Pigmenti definitive diagnosis was established by histopathology skin biopsy taken from the patient's arm.

At the present moment, the patient is in multidisciplinary follow-up and the previous verrucous lesions evolved into swirled flat hyperpigmentation along the Blaschko lines, ultimately resulting in hyperchromic spots (Figure 1A and 1B). Another IP dermatological manifestation presented is cicatricial alopecia (Figure 1C).

Figure 1. Cutaneous manifestations. Hyperchromic spots on the lateral of the trunk (A), left leg (B) and area of scarring alopecia on the vertex of the scalp (C).

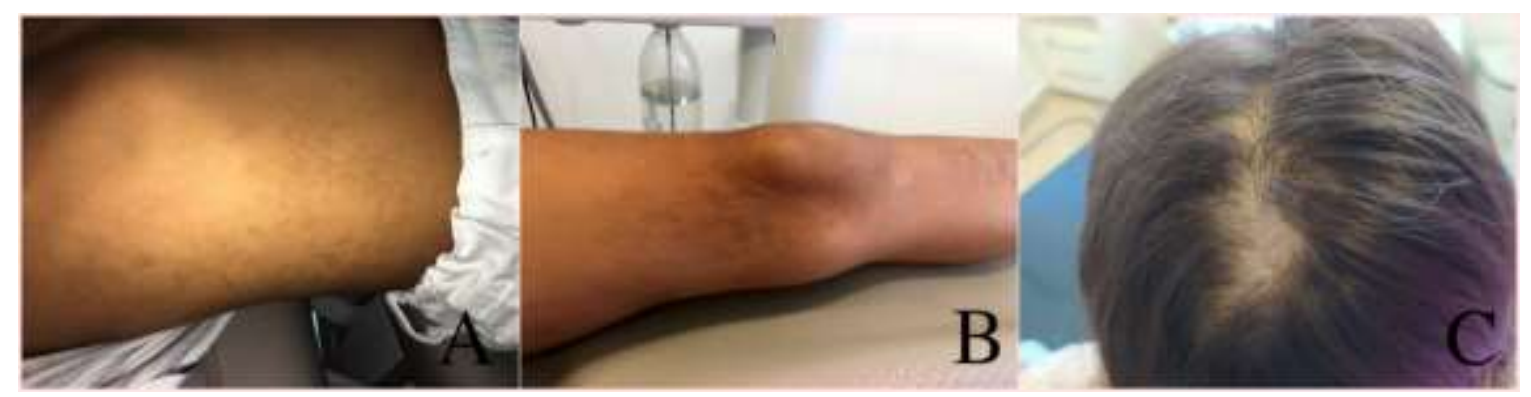

Source: Authors.

An initial oral exam was performed to assess her general oral health status and also a radiographic evaluation. During the intraoral examination, it was verified that the patient had mixed dentition, poor oral hygiene and dental amalgam filling on the first upper right molar (\#54) were also found (Figure 2A). The lower incisors presented conoid crown and a diastema 
between them (\#31 and \#32) (Figure 2B). The Figure 2C shows a left intraoral view. Topical fluoride application and oral hygiene instructions were also performed.

Figure 2. Intra-oral view showing conoid teeth and diastema. The patient's intraoral view of the first upper right molar (\#54) (A), mandibular arch with showing conoid lower incisors and a diastema (between \#31 and \#32) (B) and left intraoral view (C).

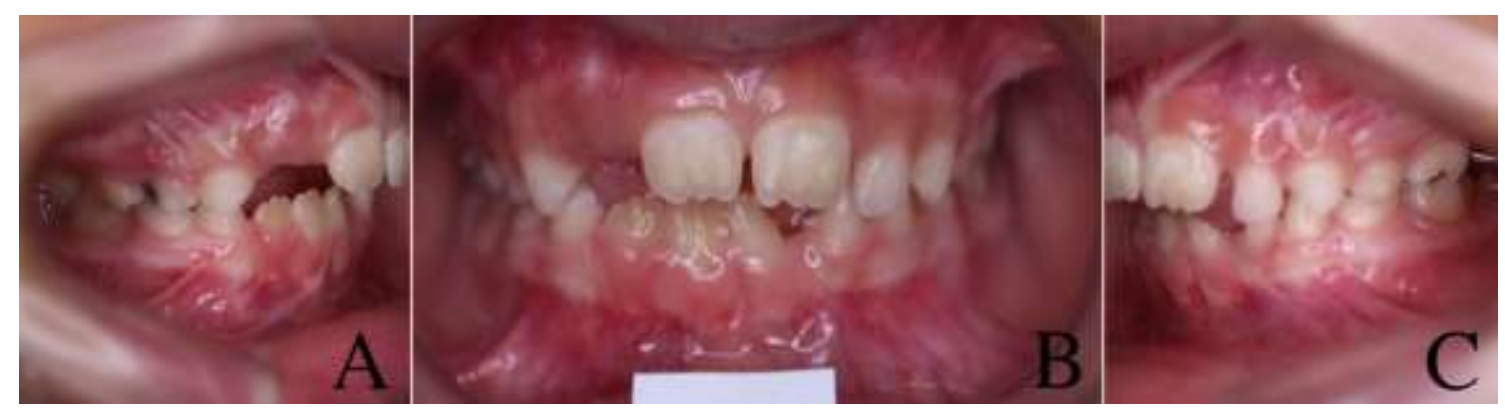

Source: Authors.

Orthopantamogram examination revealed agenesis of 7 permanent teeth: upper left lateral incisor (\#22), upper left second premolar (\#25), upper left first molar (\#26), upper left second molar (\#27), lower left second premolar (\#35), left lower lateral incisor (\#32), and lower right second premolar (\#45) (Figure 3).

Figure 3. Panoramic X-ray showed hypodontia of lateral incisor (\#22), second upper left premolar (\#25), second left lower premolar (\#35), left lower lateral incisor (\#32), second premolar lower right first molar (\#45), upper left first molar (\#26) and second left upper molar (\#27).

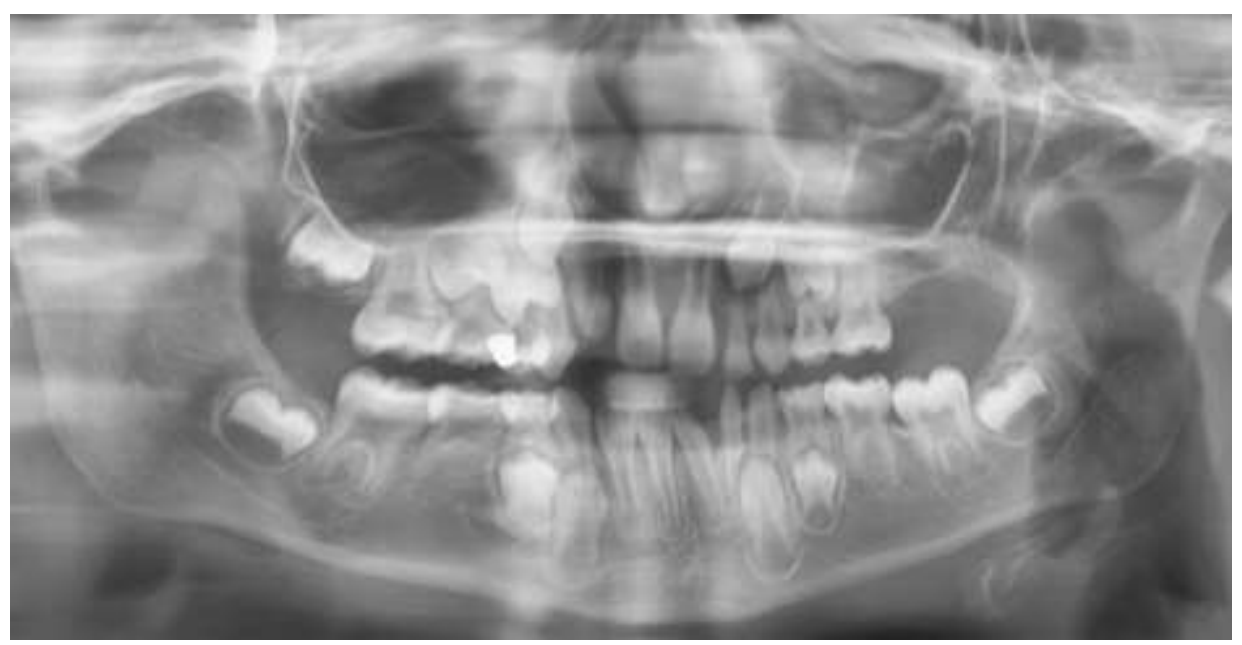

Source: Authors.

Parents were informed about the influence of IP on the child's dental condition, and a thorough consultation was conducted with her mother's involvement about possible future dental treatment options. Six months after the initial dental treatment, the child returned to a follow-up preventive and was performed a sealant application in first permanent molars, a topical fluoride application, oral hygiene and dietary instruction.

The patient was instructed to remain in monitoring dental care with a pediatric dentist and also an orthodontist for preventive dental to maintain oral health every 6 months for the treatment and an appropriate follow-up. Since skeletal and 
occlusion relationships may be influenced by growth during puberty, therapy with implants has been suggested after a growth spurt.

\section{Discussion}

Incontinentia Pigmenti is a rare systemic disease, involving ectodermal tissues, and it is characterized by dental, ocular, skin and neurological manifestations (Chen \& Chen, 2017; Dubois et al., 2020; Iguchi et al., 2019; Moro et al., 2020). In this report, we describe a patient with several dental alterations and without ocular and neurological manifestations.

Dental abnormalities, most commonly reported in patients with IP, are not pathognomonic signs of this syndrome, since they are also present in other congenital disorders, such as ectodermal dysplasia and syphilis (Wagner, 1997). The literature describes that 2 to $10 \%$ of the normosystemic population has agenesis, whereas in patients with IP this rate is around 34\% (Moro et al., 2020; Cao et al., 2017; Wagner, 1997; Al-Abdallah et al., 2015). It has also been reported that partial anodontia affects $43.1 \%$ of IP patients (Chen \& Chen, 2017).

The reported patient presents agenesis of 7 permanent teeth, which are the most common dental findings found in IP patients, according to Al-Abdallahet et al. (2015). However, in the case series presented by Santa-Maria et al. (2017), anomalies in dental crowns were the most frequent oral features identified, occurring in $71.4 \%$ of cases, with the central incisor being the most affected.

Normally, in cases of agenesis of the permanent teeth, root resorption of primary teeth does not occur, which can determine a longer permanence of the deciduous teeth (Aktan et al., 2012). In cases of loss of primary teeth without a permanent successor, treatment with space maintainers, prostheses or implants will be necessary (Nadelman et al., 2020; Guariza-Filho et al., 2018). Due to the patient's young age, it is expected to keep primary teeth as long as possible or at least until the patient reaches maturity to undergo more extensive treatments.

In addition, the dental agenesis in IP patients has great significance, thus it should be emphasized the importance of improving the social adaptation and acceptance of these individuals (Poziomczyk et al., 2014). However, in this case, dental alterations still do not have such an impact on the patient's life, since she is still in the mixed dentition phase. In this case report, just one primary tooth was absent despite the agenesis of multiple permanent teeth, which will certainly imply a challenge for her dental treatment and require rigorous planning with a multi professional team.

The appearance of conoid teeth in patients with IP is often reported (Cao et al., 2017; Al-Abdallah et al., 2015; SantaMaria et al., 2017). A harmonic smile has a great influence on the life and self-esteem of children and conoid teeth can cause diastemas and aesthetic dissatisfaction, which was a patient's complaint of this report. Orthodontic treatment for correction of diastemas and subsequent re-anatomization of the conoid teeth was suggested as a future treatment.

Dental manifestations appear in a variable degree in IP patients, requiring the multidisciplinary professionals to periodically monitor and establish preventive protocols, especially caries risk assessment. It is recommended that IP patients seek dental care around 6 months of age or by the first tooth's eruption. For the maintenance of the primary dentition for a longer time, good oral hygiene practices and dietary guidelines must be followed to avoid injuries and tooth loss due to caries. The patient in this report underwent preventive and restorative dental treatment as needed, and oral hygiene was improved after frequent reinforcements. The treatment is being monitored and the appropriate moment for orthodontic and rehabilitation treatment will be future planned.

Interestingly, in the present case, despite several dental features having been identified, the parents were not previously warranted about dental alterations that can be associated with this disorder, highlighting the importance of a multidisciplinary approach which includes dental professionals. 
Knowledge about these manifestations and early dental follow-up allows mitigating the oral and dental sequelae of this syndrome. Early monitoring and guidance to parents should be valued, as malformation of the teeth can affect facial development, chewing, development of speech and appearance.

\section{Conclusion}

This case report shows IP dental abnormalities in a six-year-old girl. We emphasize the need for the dentist to be aware of dental alterations presented in this disorder so that the patient can be treated properly. It is recommended to monitor oral health as well as to carry out an appropriate therapeutic approach for the rehabilitation of the patient.

\section{Acknowledgements}

The authors would like to express their utmost gratitude to the patient and parents who consented for this case report to be published.

\section{Conflict of Interest Statement}

All authors declare that they have no conflict interest.

\section{Ethics Statement}

All patient information was exposed anonymously. The legal guardians for the patient in the present case signed an informed consent form. The manuscript content is original work and has not been published or submitted elsewhere. The submission is made on behalf of all authors. I confirm that I have read and understood the journal's guidelines on matters pertaining to the copyright, authorship as well as ethical and legal requirements of the study country.

\section{References}

Aktan, A. M., Kara, I., Sener, I., Bereket, C., Celik, S., Kirtay, M., Ciftçi, M. E., \& Arici, N. (2012). An evaluation of factors associated with persistent primary teeth. European journal of orthodontics, 34(2), 208-212. https://doi.org/10.1093/ejo/cjq189

Al-Abdallah, M., AlHadidi, A., Hammad, M., Al-Ahmad, H., \& Saleh, R. (2015). Prevalence and distribution of dental anomalies: a comparison between maxillary and mandibular tooth agenesis. American journal of orthodontics and dentofacial orthopedics: official publication of the American Association of Orthodontists, its constituent societies, and the American Board of Orthodontics, 148(5), 793-798. https://doi.org/10.1016/j.ajodo.2015.05.024

Berlin, A. L., Paller, A. S., \& Chan, L. S. (2002). Incontinentia pigmenti: a review and update on the molecular basis of pathophysiology. Journal of the American Academy of Dermatology, 47(2), 169-190. https://doi.org/10.1067/mjd.2002.125949

Cammarata-Scalisi, F., Fusco, F., \& Ursini, M. V. (2019). Incontinentia Pigmenti. Incontinencia pigmenti. Actas dermo-sifiliograficas, 110(4), 273-278. https://doi.org/10.1016/j.ad.2018.10.004

Cao, H., Alrejaye, N., Klein, O. D., Goodwin, A. F., \& Oberoi, S. (2017). A review of craniofacial and dental findings of the RASopathies. Orthodontics \& craniofacial research, 20 Suppl 1(Suppl 1), 32-38. https://doi.org/10.1111/ocr.12144

Chen, A. Y., \& Chen, K. (2017). Dental treatment considerations for a pediatric patient with incontinentia pigmenti (Bloch-Sulzberger syndrome). European journal of dentistry, 11(2), 264-267. https://doi.org/10.4103/ejd.ejd_95_17

Dubois, P., Chapron, T., Affortit-Demoge, A., Martin, G., Caputo, G., \& Metge-Galatoire, F. (2020). Incontinentia Pigmenti: Homozygous twins with asymmetric ocular involvement. Journal francais d'ophtalmologie, 43(8), e289-e292. https://doi.org/10.1016/j.jfo.2019.12.016

Guariza-Filho, O., Araujo, C. M., Schroder, A., Tanaka, O. M., Kern, R., \& Ruellas, A. C. (2018). Prosthetic, orthodontic and implant-supported rehabilitation of five maxillary anterior teeth with alveolar bone loss. Dental press journal of orthodontics, 23(1), 87-96. https://doi.org/10.1590/2177-6709.23.1.087096.oar

Iguchi, A., Aoki, Y., \& Kitazawa, K. (2019). Progressive skin rashes of incontinentia pigmenti during infancy. Pediatrics international: official journal of the Japan Pediatric Society, 61(10), 1065-1066. https://doi.org/10.1111/ped.13964

Landy, S. J., \& Donnai, D. (1993). Incontinentia pigmenti (Bloch-Sulzberger syndrome). Journal of medical genetics, 30(1), 53-59. https://doi.org/10.1136/jmg.30.1.53 
Research, Society and Development, v. 10, n. 9, e50310917482, 2021

(CC BY 4.0) | ISSN 2525-3409 | DOI: http://dx.doi.org/10.33448/rsd-v10i9.17482

Marques, G. F., Tonello, C. S., \& Sousa, J. M. (2014). Incontinentia pigmenti or Bloch-Sulzberger syndrome: a rare X-linked genodermatosis. Anais brasileiros de dermatologia, 89(3), 486-489. https://doi.org/10.1590/abd1806-4841.20143043

Minić, S., Trpinac, D., \& Obradović, M. (2014). Incontinentia pigmenti diagnostic criteria update. Clinical genetics, 85(6), 536-542. https://doi.org/10.1111/cge.12223

Moro, R., Fabiano, A., Calzavara-Pinton, P., Cardinale, J., Palumbo, G., Giliani, S., Lanzi, G., Antonelli, F., De Simone, M., Martelli, P., Fazzi, E., Pinelli, L., \& Gualdi, G. (2020). Incontinentia Pigmenti Associated with Aplasia Cutis Congenita in a Newborn Male with Klinefelter Syndrome: Is the Severity of Neurological Involvement Linked to Skin Manifestations? Dermatology and therapy, 10(1), 213-220. https://doi.org/10.1007/s13555-019-00336-Z

Nadelman, P., Gárate, K. M., Oliveira, A., Pithon, M. M., de Castro, A., \& Maia, L. C. (2020). Dental arch perimeter changes as a result from premature loss of primary anterior teeth due to trauma: A case series in infant and pre-school children. International journal of paediatric dentistry, 10.1111 ipd.12738. Advance online publication. https://doi.org/10.1111/ipd.12738

Poziomczyk, C. S., Recuero, J. K., Bringhenti, L., Maria, F. D., Campos, C. W., Travi, G. M., Freitas, A. M., Maahs, M. A., Zen, P. R., Fiegenbaum, M., Almeida, S. T., Bonamigo, R. R., \& Bau, A. E. (2014). Incontinentia pigmenti. Anais brasileiros de dermatologia, 89(1), 26-36. https://doi.org/10.1590/abd1806-4841.20142584

Santa-Maria, F. D., Mariath, L. M., Poziomczyk, C. S., Maahs, M., Rosa, R., Zen, P., Schüller-Faccini, L., \& Kiszewski, A. E. (2017). Dental anomalies in 14 patients with IP: clinical and radiological analysis and review. Clinical oral investigations, 21(5), 1845-1852. https://doi.org/10.1007/s00784-016-1977-y

Smahi, A., Courtois, G., Vabres, P., Yamaoka, S., Heuertz, S., Munnich, A., Israël, A., Heiss, N. S., Klauck, S. M., Kioschis, P., Wiemann, S., Poustka, A., Esposito, T., Bardaro, T., Gianfrancesco, F., Ciccodicola, A., D'Urso, M., Woffendin, H., Jakins, T., Donnai, D., ... Nelson, D. L. (2000). Genomic rearrangement in NEMO impairs NF-kappaB activation and is a cause of incontinentia pigmenti. The International Incontinentia Pigmenti (IP) Consortium. Nature, 405(6785), 466-472. https://doi.org/10.1038/35013114

Wagner A. (1997). Distinguishing vesicular and pustular disorders in the neonate. Current opinion in pediatrics, 9(4), 396-405. https://doi.org/10.1097/00008480-199708000-00015

Yang, Y., Guo, Y., Ping, Y., Zhou, X. G., \& Li, Y. (2014). Neonatal incontinentia pigmenti: Six cases and a literature review. Experimental and therapeutic medicine, 8(6), 1797-1806. https://doi.org/10.3892/etm.2014.2011 